\title{
Gregarine species (Apicomplexa) parasitic in the burrowing echinoid Echinocardium cordatum: occurrence and host reaction
}

\author{
Pierre Coulon \& Michel Jangoux
}

Laboratoire de Biologie marine (CP 160), Université Libre de Bruxelles, Ave F. D. Roosevelt 50, B-1050 Bruxelles, Belgium

\begin{abstract}
Five species of gregarines co-occur in individuals of a North Sea population of Echinocardium cordatum, viz. 3 intracoelomic species (Urospora neapolitana, Lithocystis foliacea, L. schneideri) and 2 intrahemal species (Urospora sp., Lithocystis sp.). E. cordatum become infested by swallowing sediment containing ripe gametocysts. Sporozoites penetrate only the digestive cells of the gastric caecum where early growth of trophozoites occurs. Trophozoites reach either the host's ambulacral hemal lacunae or the host's body cavity where further growth occurs. Whether the species is intrahemal or intracoelomic, gametocysts accumulate in the echinoid body cavity. They are released at the host's death. Conspicuous coelomocyte reactions occur against gregarine intracoelomic free stages, leading to the death of the parasites. Coelomocyte reaction is more intense against paired gregarines (i.e. syzygies) than single ones (i.e. trophozoites). Sensitivity to coelomocytes varies between different gregarine species.
\end{abstract}

\section{INTRODUCTION}

To date gregarinoses of echinoderms have been attributed only to eugregarines of the family Urosporidae, which mostly infest deposit-feeding echinoderms. Among the 22 species known from echinoderms, 14 are found in holothuroids, and 8 infest spatangoid echinoids (for review see Jangoux 1987). The common European spatangoid Echinocardium cordatum may house up to 4 different species of gregarines in its body cavity (Léger 1896, 1897, PixellGoodrich 1915). The external morphology of their oocysts has been described, but their life-cycles are poorly understood. It is known, however, that $E$. cordatum may develop conspicuous reactions against intracoelomic free stages of gregarines as peculiar aciculate coelomocytes often surround trophozoites (De Ridder \& Jangoux 1984). The present paper characterizes the gregarine species infesting a North Sea population of $E$. cordatum and considers the efficiency of the host reaction against the parasites.

\section{MATERIALS AND METHODS}

Adult individuals of Echinocardium cordatum (Pennant 1777) (body length: $48.9 \pm 2.5 \mathrm{~mm}$; body width: $49.2 \pm 2.8 \mathrm{~mm}$ ) were collected intertidally at Wimereux (Pas de Calais, France) in March 1985. They were maintained for 3 to $6 \mathrm{~d}$ in a closed-circuit marine aquarium in the laboratory at Brussels $\left(10^{\circ} \mathrm{C} ; 30 \%\right.$ salinity) before examination.

Identifications, countings and measurements of gregarine intracoelomic stages were made using dissecting and inverted microscopes. Movements of intracoelomic free stages were studied from video records (Sony U-Matic professional system). Observations and measurements of oocysts were made on smears of gametocysts stained with a $1 \%$ aqueous solution of methylene blue. For SEM observations, intracoelomic stages were fixed for $2 \mathrm{~h}$ at $4{ }^{\circ} \mathrm{C}$ in a solution of $3 \%$ glutaraldehyde and cacodylate buffer $(0.1 \mathrm{M}, \mathrm{pH}$ 7.4), washed in buffer, postfixed with $0.1 \%$ osmium tetroxide in $0.1 \mathrm{M}$ cacodylate buffer, and washed again in buffer. Postfixed intracoelomic stages were dehydrated in graded ethanol and dried by the critical point method, using $\mathrm{CO}_{2}$ as transition fluid. They were mounted on aluminium stubs, coated with gold in a sputter coater and observed with a ISI DS-130 scanning electron microscope.

Searching for infesting stages (i.e. sporozoites) was done on sections of digestive organs. For light microscopy, organs were fixed in Bouin's fluid (without acetic acid), embedded in paraplast and cut into $7 \mu \mathrm{m}$ 
sections. Sections were stained according to the procedure of Ganter \& Jollès (1969). The routine stains used were Masson trichrome and the May-GrunwaldGiemsa technique. For TEM observations, fragments of digestive organs were fixed, postfixed and dehydrated as were the intracoelomic stages used for SEM investigations. Digestive fragments were embedded in Spurr's medium. Ultra-thin sections (LKB V ultramicrotome) were stained with uranyl acetate and lead citrate, and studied with a Philips EM 300 transmission electron microscope.

\section{RESULTS}

\section{Inventory of species}

Species recognition in spatangoid urosporids depends mainly on oocyst morphology, as the other life-stages are almost unknown. The oocysts are egg- shaped capsules walled off by a thick endospore which is itself surrounded by a closely appressed and much thinner epispore (Fig. 1). The epispore typically detaches from the oocyst capsule, forming an anterior funnel and a posterior caudal appendage. The main diagnostic features of urosporid oocysts are the overall size of the oocyst and the shape of both the funnel and the caudal appendage. Five different species of gregarines co-occurred in the investigated individuals of Echinocardium cordatum. Three of them correspond to recognized species; the remaining 2 are presumably undescribed species. The species are:

Urospora neapolitana (Pixell-Goodrich 1915) (Fig. $1 \mathrm{~A} \&$ Table 1). Small oocyst capsule (ca $13 \mu \mathrm{m}$ length); funnel short and narrow; caudal appendage filiform and spiral-like.

Lithocystis foliacea (Poxell-Goodrich 1915) (Fig. 1B \& Table 1). Long oocyst capsule (ca $24 \mu \mathrm{m}$ length); funnel conspicuous, sometimes with filamentous
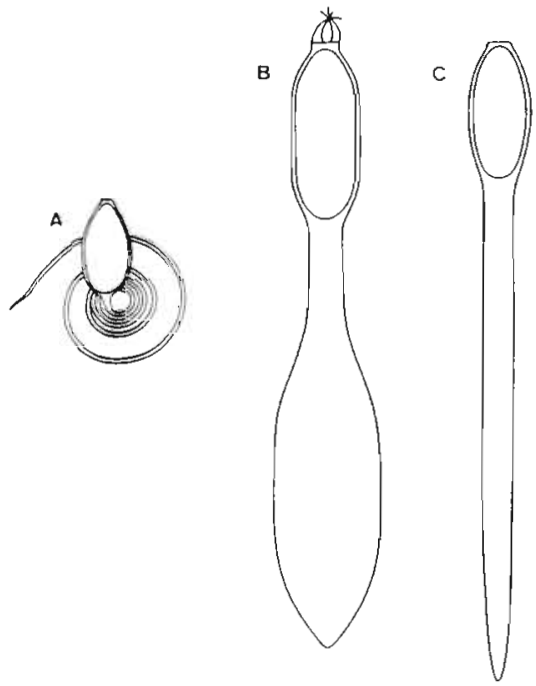

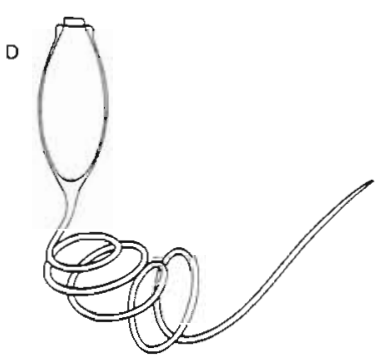

$10 \mu \mathrm{m}$

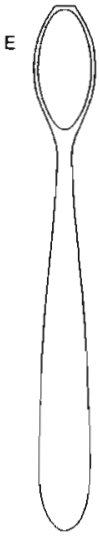

Fig. 1. Gregarine species infesting Echinocardium cordatum: outer morphology of oocysts. (A) Urospora neapolitana; (B) Lithocystis foliacea; (C) Lithocystis schneideri; (D) Urospora sp.; (E) Lithocystis sp.

Table 1. Measurements of gregarine oocysts. Mean value $(\mu \mathrm{m}) \pm$ confidence unit $(\mathrm{p}=0.05)$ with range

\begin{tabular}{|c|c|c|c|c|c|}
\hline Dimension & $\begin{array}{c}\text { Urospora } \\
\text { neapolitana } \\
(\mathrm{n}=29)\end{array}$ & $\begin{array}{l}\text { Lithocystis } \\
\text { foliacea } \\
(\mathrm{n}=30)\end{array}$ & $\begin{array}{l}\text { Lithocystis } \\
\text { schneideri } \\
(\mathrm{n}=26)\end{array}$ & $\begin{array}{l}\text { Urospora sp. } \\
\qquad(\mathrm{n}=25)\end{array}$ & $\begin{array}{l}\text { Lithocystis sp. } \\
\qquad(\mathrm{n}=40)\end{array}$ \\
\hline $\begin{array}{l}\text { Length of } \\
\text { oocyst capsule }\end{array}$ & $\begin{array}{c}13.0 \pm 0.6 \\
(10-14)\end{array}$ & $\begin{array}{c}24.2 \pm 0.8 \\
(20-28)\end{array}$ & $\begin{array}{c}18.4 \pm 0.9 \\
(14-24)\end{array}$ & $\begin{array}{c}22.1 \pm 1.2 \\
(18-27)\end{array}$ & $\begin{array}{c}17.1 \pm 0.5 \\
(14-24)\end{array}$ \\
\hline $\begin{array}{l}\text { Width of } \\
\text { oocyst capsule }\end{array}$ & $\begin{array}{l}6.0 \pm 0.2 \\
(5-6)\end{array}$ & $\begin{array}{c}7.9 \pm 0.3 \\
(6-10)\end{array}$ & $\begin{array}{c}7.1 \pm 0.2 \\
(6-8)\end{array}$ & $\begin{array}{c}8.5 \pm 0.5 \\
(7-10)\end{array}$ & $\begin{array}{l}7.1 \pm 0.3 \\
(6-8)\end{array}$ \\
\hline $\begin{array}{l}\text { Length of } \\
\text { caudal capsule }\end{array}$ & $\mathrm{ca} 90^{\mathrm{b}}$ & $\begin{array}{c}59.2 \pm 2.6 \\
(42-74)\end{array}$ & $\begin{array}{c}71.3 \pm 4.2 \\
(54-90)\end{array}$ & ca $140^{\circ}$ & $\begin{array}{c}55.9 \pm 2.3 \\
(43-72)\end{array}$ \\
\hline $\begin{array}{l}\text { Width of } \\
\text { caudal appendage }\end{array}$ & $\operatorname{ca} 1^{\mathrm{b}}$ & $\begin{array}{c}13.1 \pm 0.5 \\
(10-16)\end{array}$ & $\begin{array}{c}4.0 \pm 0.2 \\
(4-6)\end{array}$ & $\mathrm{ca} 2^{\mathrm{b}}$ & $\begin{array}{c}6.4 \pm 0.3 \\
(6-8)\end{array}$ \\
\hline
\end{tabular}


extensions; caudal appendage flattened and distally enlarged.

Lithocystis schneideri (Giard 1876) (Fig. 1C \& Table 1). Middle-sized oocyst capsule (ca $18 \mu \mathrm{m}$ length); funnel short and wide; caudal appendage tubulous with pointed distal extremity.

Urospora sp. (Fig. 1D \& Table 1). Middle-sized oocyst capsule (ca $22 \mu \mathrm{m}$ length); funnel elongated and narrow, surrounded by a corolla; caudal appendage very long and spiral-like (at least in its proximal part).

Lithocystis sp. (Fig. 1E \& Table 1). Middle-sized oocyst capsule (ca $17 \mu \mathrm{m}$ length); funnel short and wide; caudal appendage flattened, constricted proximally and slightly enlarged distally, with rounded distal extremity.

Gametocysts of Urospora neapolitana, Lithocystis foliacea and $L$. schneideri were seen only in the coelomic cavity while those of the unidentified species were detected also within the hemal lacunae of the apical tube feet ampullae (Urospora sp.) and the respiratory tube feet ampullae (Lithocystis sp.). The cysts of both Urospora sp. and Lithocystis sp. are pro- gressively expelled into the coelomic cavity where they co-occur with cysts of other strictly intracoelomic species.

\section{Sporozoites and early trophozoites}

The digestive organs of 30 Echinocardium cordatum were histologically surveyed and gregarines were found only in the gastric caecum. (The gastric caecum is an enlarged fluid-filled organ that opens at the very beginning of the spatangoid stomach; De Ridder \& Jangoux 1982.) Early trophozoites were observed in the digestive cells of all investigated caeca. They are rod-to egg-shapped cells of 4 to $10 \mu \mathrm{m}$ length that are easily recognizable on sections stained by the MayGrünwald-Giemsa technique. Sporozoites penetrate the host cell through microvilli (Fig. 2) and migrate down the cell cytoplasm enclosed in a conspicuous vacuole. Early trophozoites have numerous paraglycogen granules that occupy most of the cell volume (Fig. 3).

\section{2}

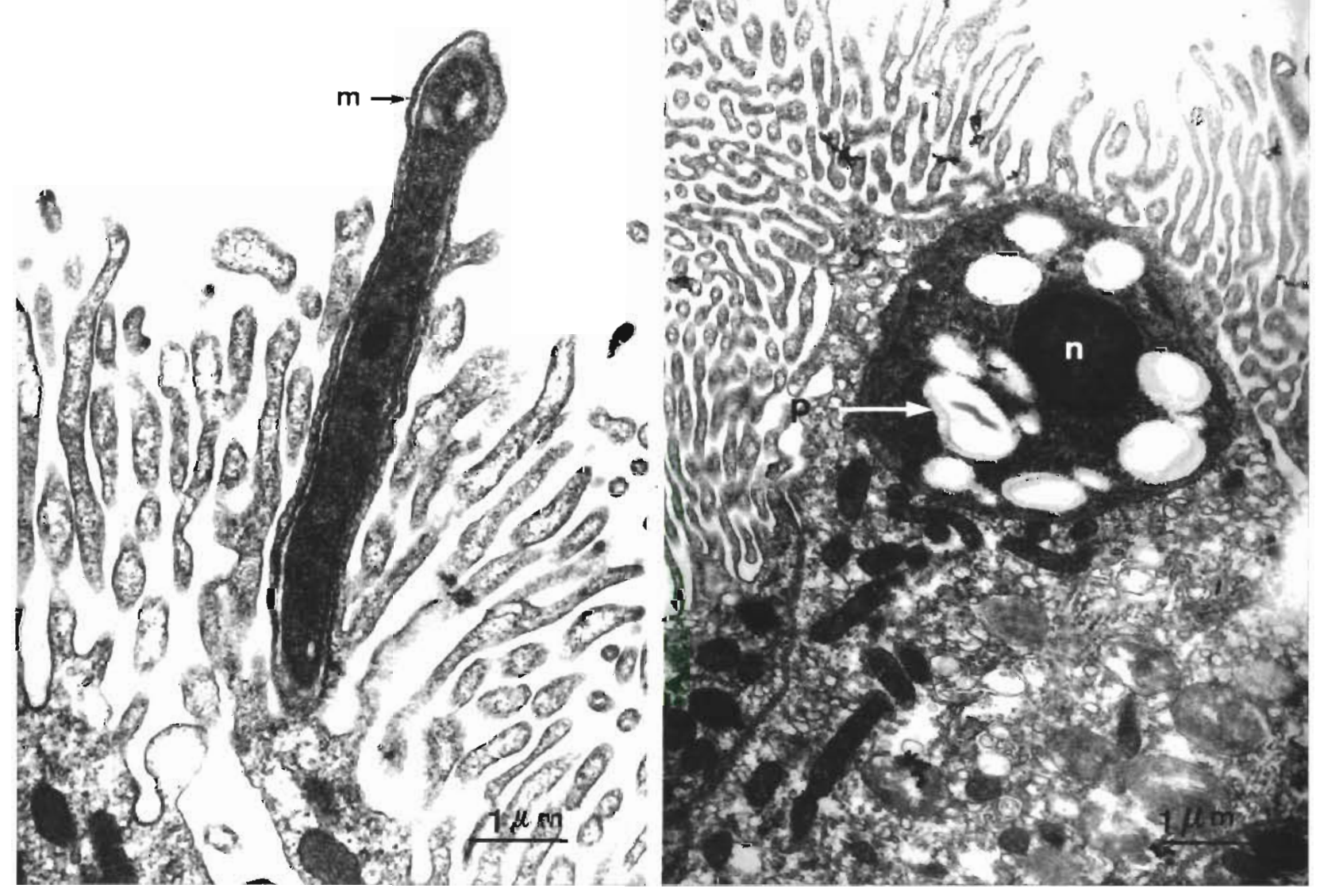

Fig. 2 \& 3. Intradigestive stages of gregarine (unidentified species) from Echinocardium cordatum. Fig. 2. Infesting sporozoite. Fig. 3. Early trophozoite. m: microvilli of host's cell; $\mathrm{n}$ : gregarine nucleus; p: paraglycogene granule 


\section{Intracoelomic trophozoites}

Three types of trophozoites occurred in the coelomic cavity of the investigated echinoids; they differ from each other by their shape, size and movements.
Type 1 trophozoites are presumably referable to Urospora neapolitana (see 'Discussion'). They are small worm-like individuals, 120 to $320 \mu \mathrm{m}$ long and 30 to $80 \mu \mathrm{m}$ wide (Fig. 4 \& 5). Living trophozoites typically have a tapered, hyaline anterior extremity.
4
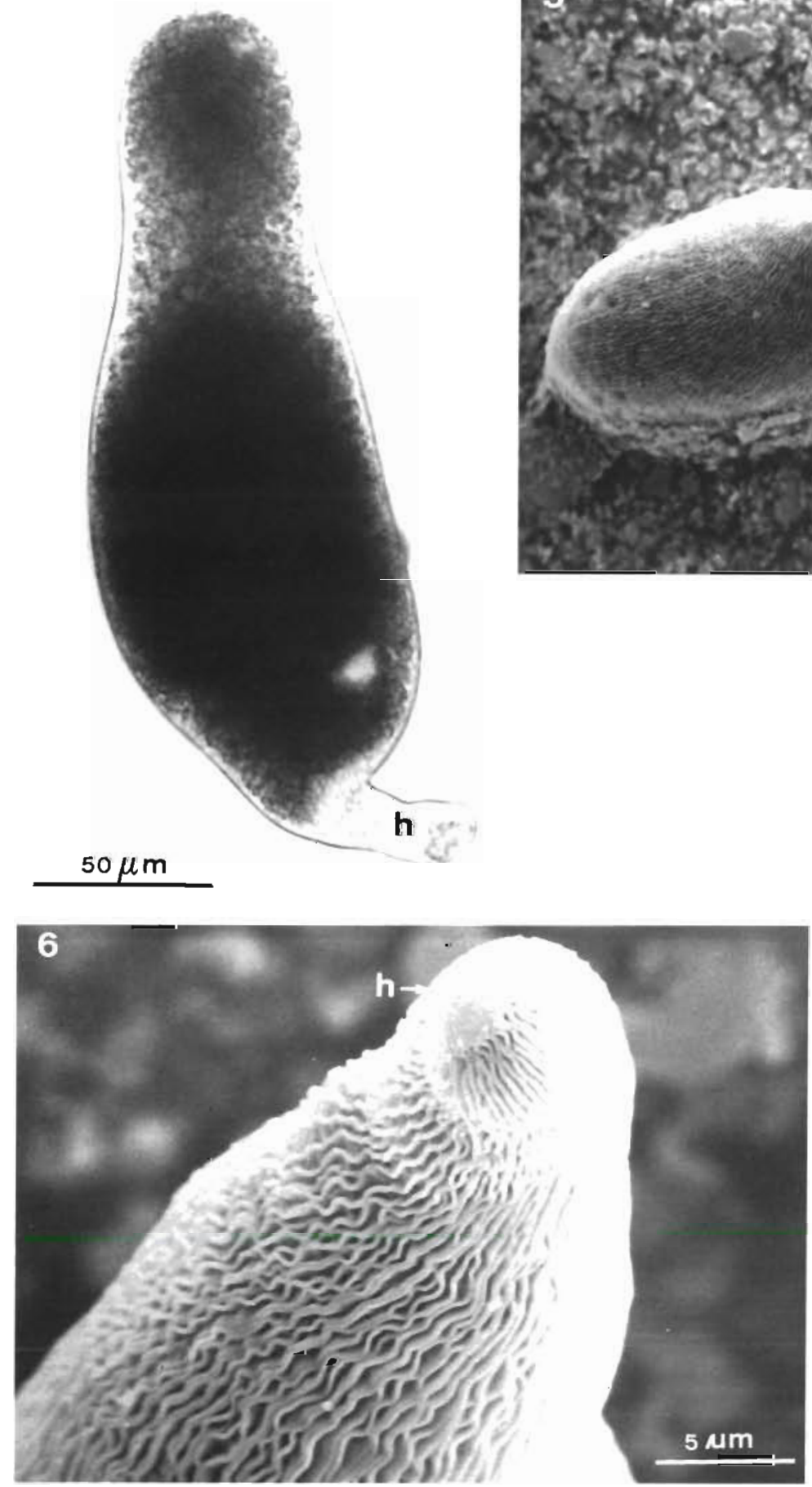
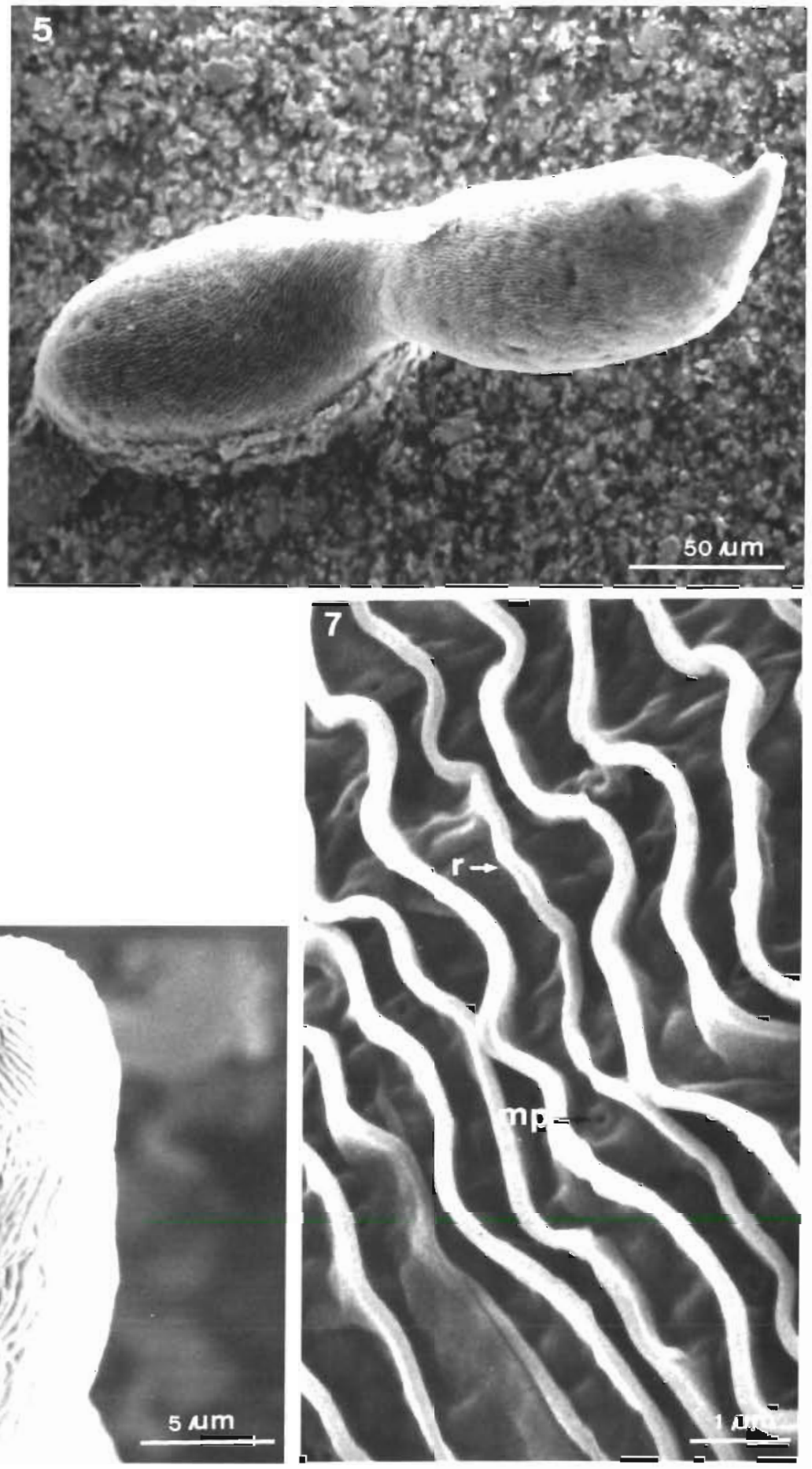

Fig. 4 to 7. Urospora neapolitana. Intracoelomic trophozoites. Fig. 4 \& 5. Outer aspect. Fig. 6. Enlarged view of the anterior extremity. Fig. 7. Detailed view of the outer ridges and micropores. h: hyaline anterior extremity; mp: micropore; r: outer ridge. (Fig. 4: phase contrast microscopy; Fig. 5 to 7 : scanning electron microscopy) 
Except for the cell's most anterior part, the cytoplasm is distinctly granular. The nucleus is round and located in the posterior half of the cell. Trophozoites of $U$. neapolitana creep on the coelomic wall of the host, moving by longitudinal contraction waves (wave period ca $1.5 \mathrm{~s}$; time between 2 successive waves ca 1 s). Spiral-like movements also occur along the trophozoite long axis. SEM-observations of the trophozoite surface showed well-developed and closely packed sinuous ridges that give the whole individual a wrinkled aspect (Fig. 5 \& 6). Between the ridges the outer surface is rather corrugated and bears scattered micropores of ca $100 \mathrm{~nm}$ in diameter (Fig. 7).

Type 2 trophozoites are prosumably referable to
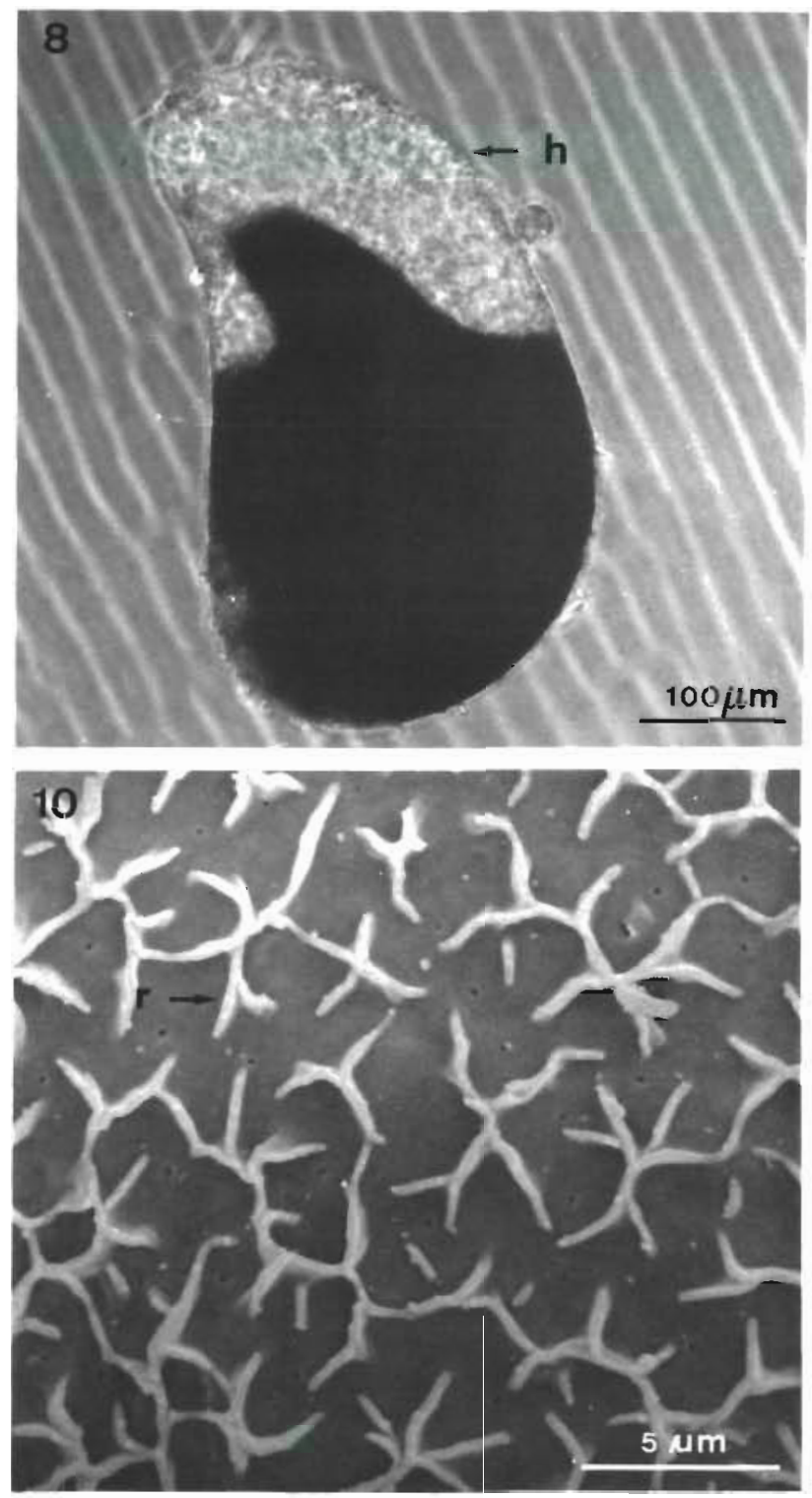

Fig. 8 to 11. Lithocystis foliacea. Intracoelomic trophozoites. Fig. 8 \& 9. Outer aspect. Fig. 10 \& 11. Detailed view of outer ridges and micropores. h: hyaline cytoplasm; mp: micropore; r: outer ridge. (Fig. 8: phase contrast microscopy; Fig. 9 to 11. scanning electron microscopy)
Lithocystis foliacea (see 'Discussion'). They are pearshaped individuals, from 300 to $560 \mu \mathrm{m}$ long and 160 to $320 \mu \mathrm{m}$ wide (Fig. 8 \& 9). The cytoplasm is divided into hyaline and dense granular areas (Fig. 8). The latter occupies about two-thirds of the cell volume and includes a round-shaped nucleus. Living trophozoites of L. foliacea do not move, but individuals continuously change shape, giving the impression of coiling up while staying on the spot. The trophozoite surface shows rosette-like structures that correspond to dotted line-like ridges from which short lateral branches arise in places (Fig. 10 \& 11). Ridges delimitate small flat areas which generally contain a single micropore (diameter ca $100 \mathrm{~nm}$ ) (Fig. 11).
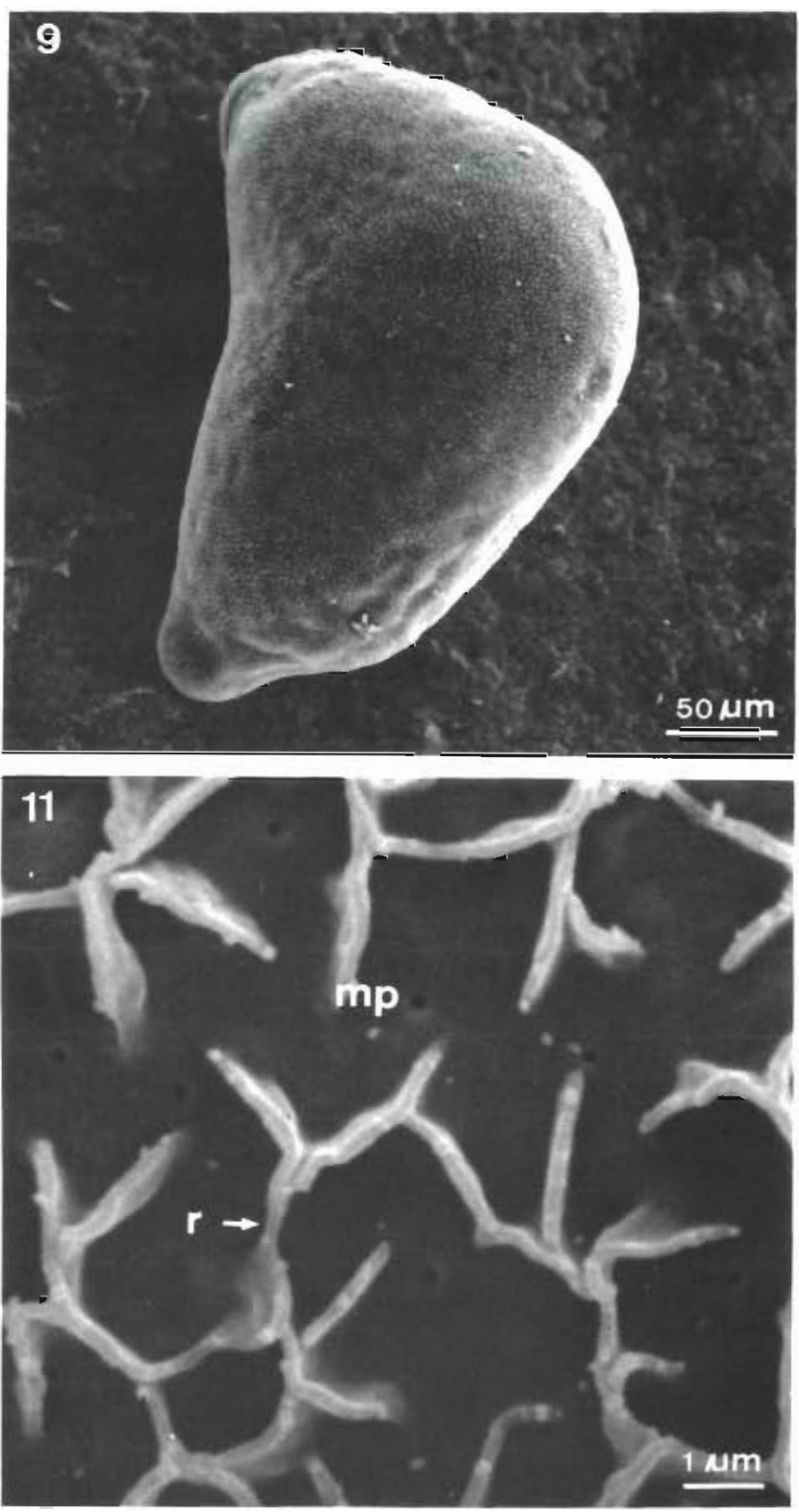
Type 3 trophozoites belong to the species Lithocystis schneideri. They are large worm-like individuals from 400 to $1850 \mu \mathrm{m}$ long and 30 to $240 \mu \mathrm{m}$ wide (Fig. 12 \& 13). The cytoplasm is divided into hyaline and granular areas. The latter occupies about three-quarters of the cell volume and includes an egg-shaped nucleus. Trophozoites of L. schneideri swim in the host coelomic fluid. They move by contraction waves that are alternatively directed backward and foreward (time between 2 successive waves ca 2 s). During wave propagation trophozoites are simultaneously driven by a spiral-like movement. Other less frequent movements also occur that consist of violent lateral beatings of one half of the trophozoite. The trophozoite surface shows regular, rather spaced and continuous ridges that run parallel to the trophozoite long axis (Fig. 14 \& 15). They delimitate flat and elongated longitudinal areas in which micropores are rather regularly distributed (diameter ca $150 \mathrm{~nm}$ ) (Fig. 15).

Absolute and relative frequencies of each type of trophozoite are given in Table 2. Trophozoites of Urospora neapolitana are common in the echinoid coelomic cavity while those of the 2 other species are rather scarce. All hosts contained trophozoites although the 3 types rarely co-occurred within a single host.

Dying and necrotic trophozoites were also seen. These trophozoites were not identifiable to species;

12
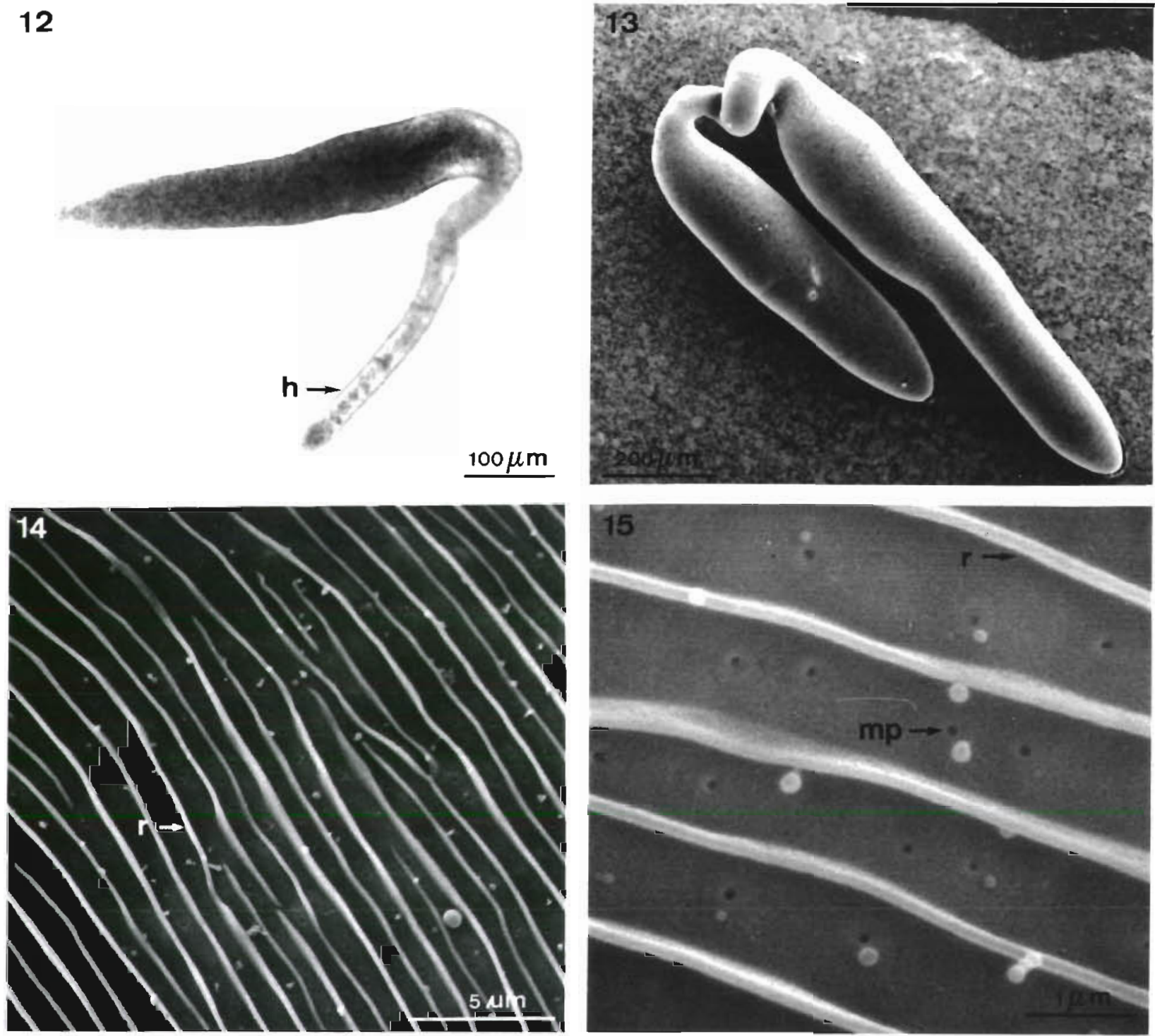

Fig. 12 to 15. Lithocystis schneideri. Intracoelomic trophozoites. Fig. 12 \& 13. Outer aspect. Fig. 14 \& 15. Detailed view of outer ridges and micropores. h: hyaline cytoplasm; mp: micropore; r: outer ridge. (Fig. 12: phase contrast microscopy; Fig. 13 to 15: scanning electron microscopy) 
they occurred in most investigated hosts where they represented up to $80 \%$ of the total number of trophozoites (Table 3). They were of various sizes (from $200 \mu \mathrm{m}$ to more than $1 \mathrm{~mm}$ length) and shapes (rod-, round- or egg-shaped). Some of them showed only slight movements and had a pincushion aspect being covered by aciculate coelomocytes (De Ridder \& Jangoux 1984) (Fig. 18 \& 19); some others were motionless and dotted with dark patches supposedly made of degenerated coelomocytes.

\section{Syzygies}

All the observed healthy syzygies were X-shaped and consisted of paired individuals attached through the middle (Fig. 16). Syzygian gamonts were similar to Lithocystis schneideri trophozoites. They were of various size (from 300 to $1600 \mu \mathrm{m}$ length), the paired individuals being always equally-sized. Their movements resembled those of $L$. schneideri trophozoites, the attached individuals showing synchronous contraction waves. Dying syzygies consisted of gamonts with a pincushion appearance (Fig. 17). They were made of rod- or egg-shaped individuals closely applied to each other. Healthy syzygies were found in only 3 of the 30 investigated hosts with a maximum of 3 syzygies per host, while dying ones were observed in 18 hosts and often occurred in high number (up to 20 dying syzygies per host) (Table 3 ).

\section{Gametocysts}

Gametocysts usually occurred in the host's coelomic cavity although a few were seen within the wall of some aboral tube foot ampullae. Single cysts were rarely observed, most of them being embedded in conspicuous brown bodies where several hundreds could be counted. Brown bodies, always present in spatangoid coelomic cavities, consist of degenerated coelomocytes and mesothelial tissues (De Ridder \& Jangoux 1984) and lie either on mesenteries or in the lowest part of the coelomic cavity. Due to compaction, cysts contained in brown bodies usually lose their spherical outline and become irregularly shaped. The content of unripe gametocysts is homogeneous and milky in colour while that of ripe cysts has a spumous aspect due to oocyst entanglement. Moreover, most ripe cysts appear to be heterogeneous, one part being spumous and the other bright white in colour; the latter consists of a mass of crystals (calcium oxalate crystals) and cytoplasmic debris (Fig. 20).

The diameter of ripe gametocysts of the 5 co-occurring species of gregarines ranged from $200 \mu \mathrm{m}$ to $2 \mathrm{~mm}$ (Fig. 21). Well-marked intraspecific variations are observed in cyst sizes, especially in the species Lithocystis schneideri. Gametocysts generally occurred in high number in each investigated host (mean value: $907 \pm 247, \mathrm{p}=0.05, \mathrm{n}=10$; range: 361 to 1369). Ripe cysts were always much more numerous

Table 2. Echinocardium cordatum. Frequencies of intracoelomic trophozoites. Mean values \pm confidence limits $(p=0.05$, $\mathrm{n}=30$ ) with range

\begin{tabular}{|lcccc|}
\hline & Urospora neapolitana & Lithocystis foliacea & Lithocystis schneideri & Total \\
\hline Absolute frequency & $20.1 \pm 7.1$ & $0.2 \pm 0.4$ & $0.4 \pm 0.3$ & $20.7 \pm 7.1$ \\
Relative frequency (\%) & $(0-72)$ & $(0-6)$ & $(0-3)$ & $(3-72)$ \\
& $(31.3 \pm 8.5$ & $1.1 \pm 2.2$ & $5.7 \pm 5.8$ & 100 \\
a Mean number per host & & $(0-31.6)$ & $(0-66.7)$ & \\
\hline
\end{tabular}

Table 3. Echinocardium cordatum. Frequencies of healthy and dying or necrotic intracoelomic trophozoites and syzygies. Mean value \pm confidence limits $(\mathrm{p}=0.05, \mathrm{n}=30$ ) with range

\begin{tabular}{|c|c|c|c|c|c|c|}
\hline & $\begin{array}{c}\text { Healthy } \\
\text { trophozoites }\end{array}$ & $\begin{array}{c}\text { Dying or necrotic } \\
\text { trophozoites }\end{array}$ & Total & $\begin{array}{l}\text { Healthy } \\
\text { syzygies }\end{array}$ & $\begin{array}{c}\text { Dying or necrotic } \\
\text { syzygies }\end{array}$ & Total \\
\hline Absolute frequency ${ }^{\circ}$ & $\begin{array}{c}20.7 \pm 7.1 \\
(3-72)\end{array}$ & $\begin{array}{c}4.8 \pm 2.0 \\
(0-22)\end{array}$ & $\begin{array}{c}25.6 \pm 7.0 \\
(4-74)\end{array}$ & $\begin{array}{c}0.13 \pm 0.21 \\
(0-3)\end{array}$ & $\begin{array}{c}3.1 \pm 2.4 \\
(0-20)\end{array}$ & $\begin{array}{c}3.2 \pm 1.9 \\
(0-20)\end{array}$ \\
\hline Relative frequency $(\%)$ & $\begin{array}{l}75.8 \pm 7.9 \\
(18.5-100)\end{array}$ & $\begin{array}{r}24.2 \pm 7.9 \\
(0-81.5)\end{array}$ & 100 & $\begin{array}{c}2.1 \pm 2.4 \\
(0-25)\end{array}$ & $\begin{array}{r}97.9 \pm 2.4 \\
(75-100)\end{array}$ & 100 \\
\hline
\end{tabular}


than unripe ones (Table 4). Most ripe cysts belong to either Urospora neapolitana, L. schneideri or Lithocystis sp. (Table 4).

\section{DISCUSSION}

Since the pioneer work of Cuénot (1892) who first recognized the gregarine nature of Lithocystis schneideri - a species previously placed by Giard (1876) among the 'Sporospermia' - 3 additional species have been described from the coelom of Echinocardium cordatum, viz. L. foliacea (Pixell-Goodrich 1915), Urospora echinocardii (Pixell-Goodrich 1915), and $U$. neapolitand (Pixell-Goodrich 1915). As reported by Levine (1977), distinction between the genera Lithocystis and Urospora is rather unclear as 'we do not know the complete life cycles of all the species, so we are dependent upon the shape of the oocysts'. Levine considered that X-shaped syzygy and calcium oxalate crystals are proper to the genus Lithocystis. This seems not true as so far Lithocystis from both holothuroids and sipunculids never have either X-shaped syzygy or calcium oxalate crystals (Pixell-Goodrich 1925, 1929, 1950). Moreover, all investigated species of Lithocystis and Urospora from spatangoids contain calcium oxalate crystals (Léger 1897, Pixell-Goodrich 1915, this
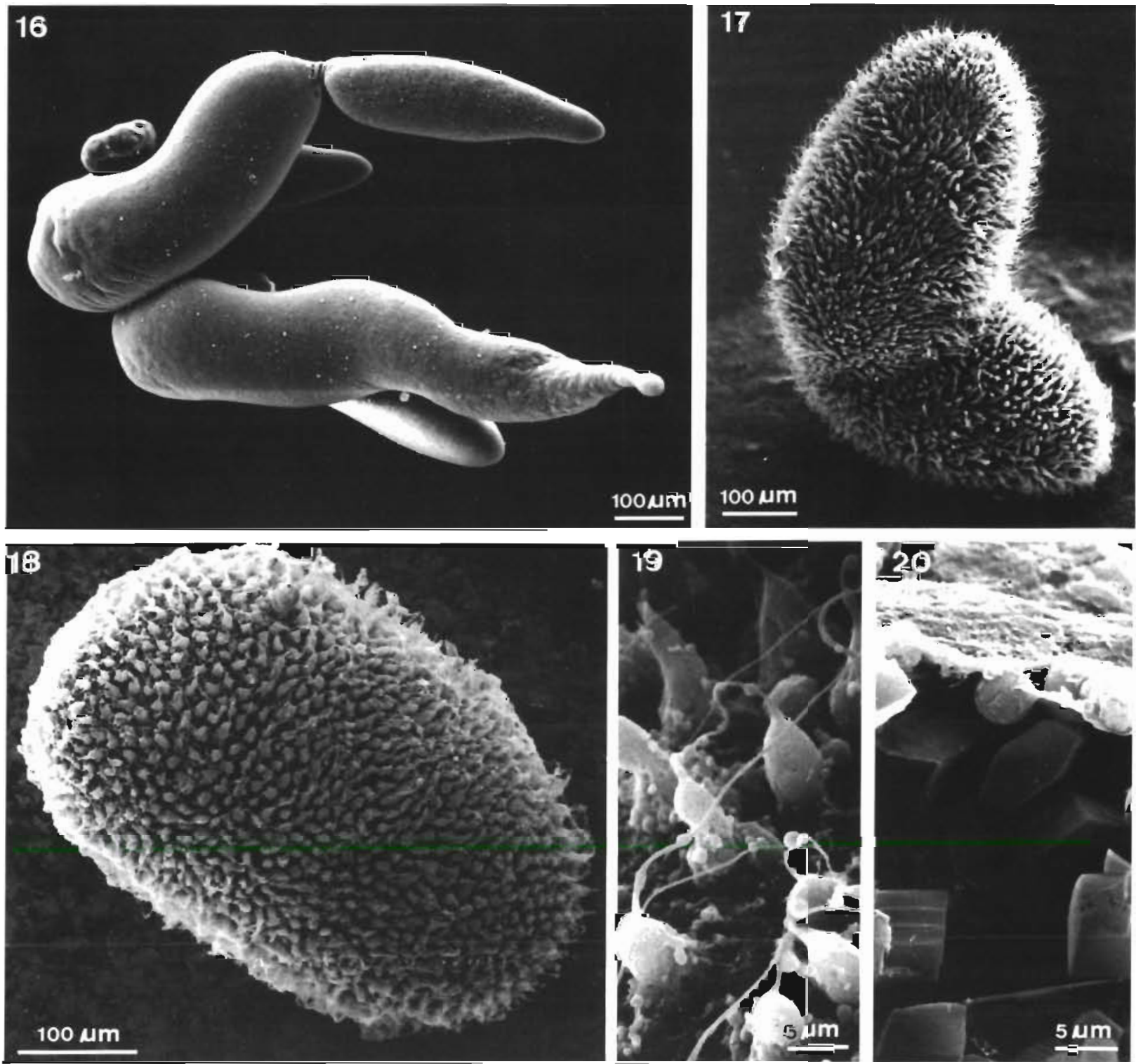

Fig. 16 to 20. Intracoelomic stages of gregarines from Echinocardium cordatum. Fig. 16. Syzygy of Lithocystis schneideri. Fig. 17. Coelomocyte-covered syzygy (unidentified species). Fig. 18. Coelomocyte-covered trophozoite (unidentified species). Fig. 19. Enlarged view of coelomocytes. Fig. 20. Broken gametocyst of $L$. schneideri showing calcium oxalate crystals 
Fig. 21 Gregarine species infesting Echinocardium cordatum: size distribution (diameter) of ripe intracoelomic gametocysts

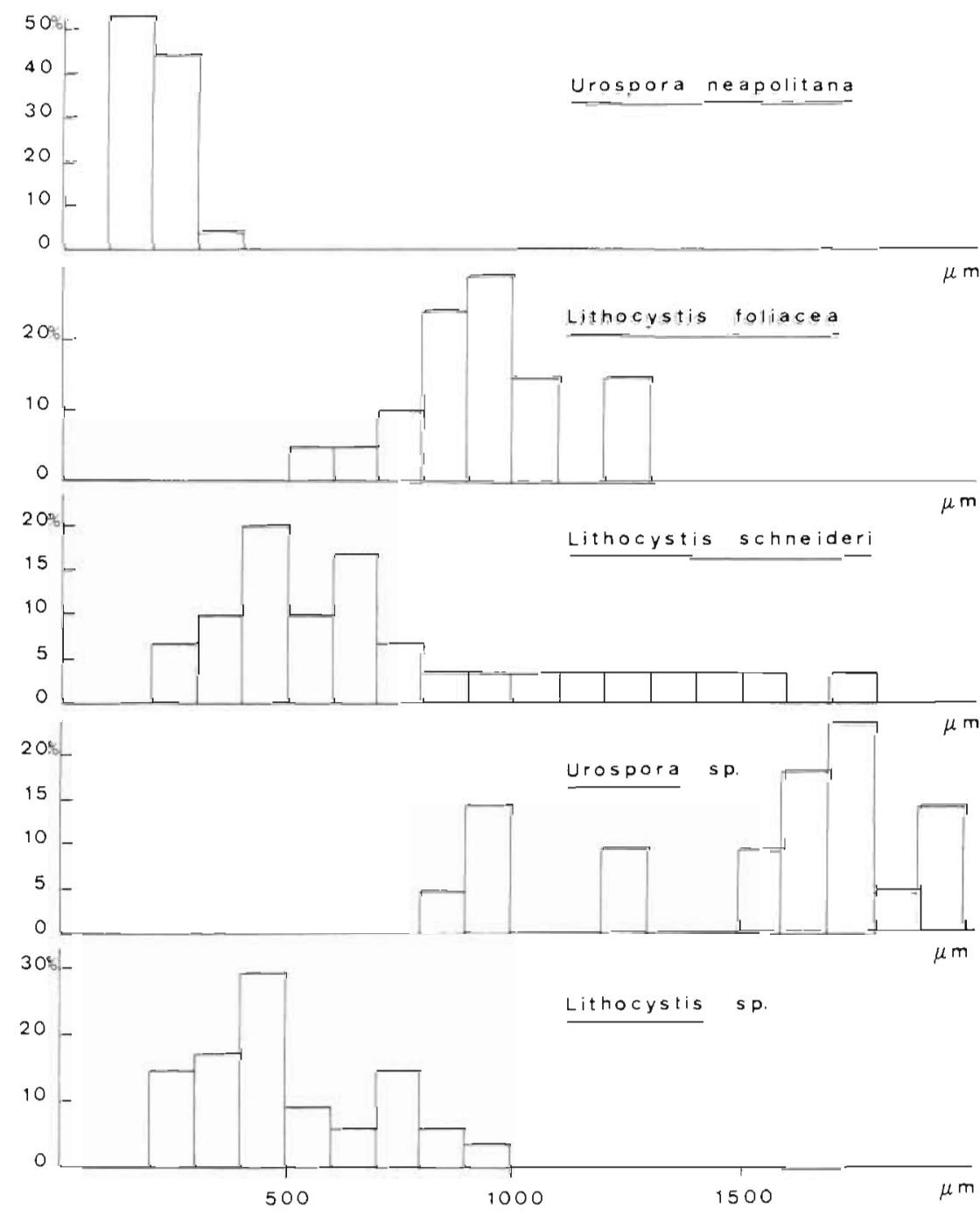

Table 4. Echinocardium cordatum. Relative frequencies $(\%)$ of gregarine gametocysts. Mean values \pm confidence limits $(\mathrm{p}=0.05 ; \mathrm{n}=20)$

\begin{tabular}{|lrl|} 
& Mean values & Range \\
\hline Unripe cysts (total) & $7.0 \pm 1.6$ & $1.8-14.3$ \\
Ripe cysts (total) & $93.0 \pm 1.6$ & $85.7-98.2$ \\
Ripe cysts of: & & \\
$\quad$ Urospora neapolitana & $36.6 \pm 8.8$ & $2.6-78.0$ \\
Lithocystis foliacea & $5.5 \pm 4.1$ & $0.0-37.7$ \\
Lithocystis schneideri & $24.9 \pm 8.6$ & $2.0-79.2$ \\
Urospora sp. & $1.3 \pm 0.8$ & $0.0-5.0$ \\
Lithocystis sp. & $21.0 \pm 7.6$ & $3.0-56.1$ \\
Unidentifiable ripe cysts & $4.3 \pm 1.8$ & $0.0-14.0$ \\
& & \\
& & \\
\end{tabular}

paper), a fact that could mean that crystal occurrence depends on the host rather than on the parasite species. We consequently used the generic characters proposed by Pixell-Goodrich (1915) who distinguished the 2 genera particularly according to the shape of the oocysts, Urospora oocysts having a filiform caudal appendage while those of Lithocystis have a ribbonlike appearence.

Based on oocyst morphology, 5 species of gregarines were recognized in the coelom of the investigated Echinocardium cordatum. Two of them have an intrahemal life cycle, their gametocysts occuring in the hemal system before reaching the coelomic cavity. The remaining 3 species (viz., Lithocystis follacea, $L$. schneideri, and Urospora neapolitana) are strictly intracoelomic. This strongly suggests that the 3 observed types of trophozoites correspond to these 3 species. Specific identifications of trophozoites are rather uneasy; they have not been described before except that of $L$. schneideri which was reported to be of large size and to form an X-shaped syzygy (Léger 1897). Correspondence of the size ranges of active 
syzygies, Type 3 trophozoites and ripe gametocysts fits Léger's description of $L$. schneideri. Size comparisons between trophozoites and cysts also suggests that Type 1 trophozoites belong to $U$. neapolitana and Type 2 to $L$. foliacea, the former having small trophozoites and gametocysts and the latter intermediate-sized ones. These diagnoses are supported in that both Type 1 trophozoites and $U$. neapolitana gametocysts are very abundant within the host coelom while Type 2 trophozoites and $L$. foliacea gametocysts are scarce (Tables $2 \& 4$ ). Our data do not allow specific recognition of sporozoites nor of unripe gametocysts, the content of the latter being always homogeneous and very similar, and lacking obvious diagnostic characters.

It is well-known that several species of gregarines may co-occur in a single echinoderm host (e.g. PixellGoodrich 1915, Changeux 1961). According to Changeux, each co-infesting intrahemal gregarine of Holothunia spp. inhabits a particular species-specific hemal area. This seems true also in Echinocardium cordatum where intrahemal species occur either in the wall of the apical tube foot ampullae (Urospora sp.) or in that of respiratory tube foot ampullae (Lithocystis sp.). Microhabitat specificity is less marked in intracoelomic gregarines although, depending on the species, trophozoites either swim in the coelomic fluid (L. schneideri) or creep on the coelomic wall (Urospora neapolitana, L. foliacea).

Individual Echinocardium cordatum become infested by swallowing sediment containing ripe gametocysts. Sporozoites penetrate only the digestive cells of the gastric caecum that lies over the stomach and never contains sediment in its lumen (De Ridder \& Jangoux 1982). This implies that both gametocyst and oocyst open in the stomach and that sporozoites migrate from there toward the caecum. Sporozoites are seemingly endocytosed by caecal cells. Early trophozoites always occur within a vacuole where they grow and accumulate conspicuous paraglycogen granules.

Until now, intrahemal gregarines were reported only from holothuroids were they usually occur in the gutassociated hemal system (e.g. Pixell-Goodrich 1925, Changeux 1961, Lützen 1968). Intrahemal gregarines also occur in spatangoids, the observed species being located, however, in the hemal lacunae of the ambulacral system (i.e. tube-foot ampullae). These gregarines presumably undergo most of their life-cycle within the hemal lacunae of the ampullae. Their gametocysts reach the host's body cavity by rupture of the wall of the infested organ, as with most intrahemal gregarines of holothuroids (e.g. Urospora synapta and Lithocystis brachycercus; Cuénot 1912, Pixell-Goodrich 1925, respectively).
Early trophozoites of intracoelomic gregarines cross the caecal wall in order to reach the host's body cavity where further growth, pairing of gamonts, and gametocyst formation occur. Intracoelomic trophozoites show particular morphological adaptations that are presumably related to their osmotrophic type of nutrition. Their outer body surface is considerably increased due to the occurrence of elongated ridges that are either straight, sinuous or star-shaped depending on the species. Intracoelomic trophozoites and gamonts may induce conspicuous reactions from the host's coelomocytes. Coelomocytes surround them and progressively change shape, becoming acicular. They enclose the whole parasite cell, giving it a pincushion appearence (De Ridder \& Jangoux 1984). According to Léger (1897), coelomocytes surround every trophozoite and gamont without affecting their normal development. In contrast, Pixell-Goodrich (1915) and Brownell \& McCauley (1971) suggest that only unhealthy individuals are attacked by coelomocytes. De Ridder \& Jangoux (1984) report that coelomocyte reaction may occur either before or just after gregarine syzygy depending presumably on gregarine motility. In vivo observations of coelomocyte-covered individuals show that they are always less active than uncovered ones, indicating that the former are either dying or necrotic. Our data indicate also that coelomocyte reaction is much more intense against paired individuals, as more than $90 \%$ of the observed syzygies were covered while no more than $25 \%$ of the trophozoites were covered (see Table 3). This suggests that paired individuals are more susceptible to coelomocytes than single ones.

High numbers of gametocysts were counted in the investigated sea urchins (up to 1350 cysts per host). Ripe cysts are always much more numerous than unripe ones. The former accumulate within the coelom and are released only at the host's death. This may mean that ripe gametocysts keep their infesting power for a long period as Echinocardium cordatum is known to be rather long-lived (up to $10 \mathrm{yr}$; Buchanan 1966, Duineveld \& Jenness 1984).

Gregarine free stages are harmful for the host (they presumably compete for energy supply) while gametocysts are innocuous. The host coelomocytes react only to gregarine coelomic free stages; gametocysts occur clustered within brown bodies but brown body formation is a natural passive process that cannot be considered a host reaction (De Ridder \& Jangoux 1984). The harmful effect of gregarines is thus directly linked to the number of free stages housed by the hosts, and occurrence of cysts is only a trail of past infections. Very few healthy syzygies were recorded from the investigated Echinocardium cordatum and coelomocyte reactions appear to be quite efficient. Moreover, species-specific sensitivity to coelomocytes is evi- 
denced as uncovered syzygies always belong to the species Lithocystis schneideri. This could explain why the host's coelom houses similar amounts of gametocysts of both L. schneideri and Urospora neapolitana although trophozoites of $U$. neapolitana occur in much larger number than those of $L$. schneideri (see Tables 2 $\& 4)$. While our data do not allow quantifying host reactions against gregarine intracoelomic free stages, one can presume that the recorded number of gametocysts result from infestation by a much higher number of sporozoites.

Acknowledgements. We thank J. Harray and M. Klinkert for technical assistance. The work was supported by an IRSIA grant to P. Coulon.

\section{LITERATURE CITED}

Brownell, C. L., McCauley, J. E. (1971). Two new parasites (Protozoa: Telosporea) from the spatangoid Brisaster latifrons. Zool. Anz. 186: 141-147

Buchanan, J. B. (1966). The biology of Echinocardium cordatum (Echinodermata: Echinoidea) from different habitats. J. mar. biol. Ass. U.K. 46: 97-114

Changeux, J. P. (1961). Contribution à l'étude des animaux associés aux holothuries. Vie Milieu 10 (Suppl.): 1-124

Cuénot, L. (1892). Commensaux et parasites des échinodermes (deuxième note). Rev. biol. nord France 5: 1-22

Cuénot, L. (1912). Contribution à la faune du Bassin d'Arcachon. V. Echinodermes. Bull. Stn biol. Arcachon 14: $17-116$

De Ridder, C., Jangoux, M. (1982). Digestive system: Echinoidea. In: Jangoux, M., Lawrence, J. M. (ed.) Echinoderm nutrition. Balkema, Rotterdam, p. 213-234

De Ridder, C., Jangoux, M. (1984). Intracoelomic parasitic
Sporozoa in the burrowing spatangoid echinoid Echinocardium cordatum: coelomocyte reaction and formation of brown bodies. Helgoländer Meeresunters. 37 : 225-231

Duineveld, G. C. A., Jenness, M. I. (1984). Differences in growth rates of the sea urchin Echinocardium cordatum as estimated by the parameter $w$ of the von Bertalanffy equation applied to skeletal rings. Mar. Ecol. Prog. Ser. 19: 65-72

Ganter, P., Jollès, G. (1969). Histochimie normàle et pathologique. Gauthier-Villars, Paris

Giard, A. (1876). Sur une nouvelle espèce de sporospermie (Lithocystis schneideri) parasite de l'Echinocardium cordatum. C.r. hebd. Séanc. Acad. Sci., Paris 82: 1208-1210

Jangoux, M. (1987). Diseases of Echinodermata. I. Agents microorganisms and protistans. Dis. aquat. Org. 2: $147-162$

Léger, L. (1896). L'évolution du Lithocystis schneideri, parasite de l'Echinocardium cordatum. C.r. hebd. Séanc. Acad. Sci., Paris 123: 702-705

Léger, L. (1897). Contribution à la connaissance des sporozoaires parasites des échinodermes: étude sur le Lithocystis schneideri. Bull. scient. Fr. Belg. 30: 241-264

Levine, N. D. (1977). Checklist of the species of the aseptate gregarine family Urosporidae. Int. J. Parasit. 7: 101-108

Lützen, J. (1968). Biology and structure of Cystobia stichopi, n. sp. (Eugregarinida, family Urosporidae), a parasite of the holothurian Stichopus tremulus Gmel. Nytt Mag. Zool. 16: $14-19$

Pixell-Goodrich, H. (1915). On the life-history of the Sporozoa of spatangoids, with observations on some allied forms. $Q$. J. microsc. Sci. 61: 81-104

Pixell-Goodrich, H. (1925). Observations on the gregarines of Chirodota. Q. J. microsc. Sci. 69: 620-628

Pixell-Goodrich, H. (1929). The gregarines of Cucumaria: Lithocystis minchinii Woodcock and Lithocystis cucumariae n. sp. Q. J. microsc. Sci. 73: 275-287

Pixell-Goodrich, H. (1950). Sporozoa of Sipunculus. Q. J. microsc. Sci. 91: 469-476 